\title{
TRADISI SYAWALAN \\ di Morodemak, Bonang, Demak
}

\author{
Khoirul Anwar \\ Program Doktor IAIN Walisongo
}

\begin{abstract}
This paper describes the tradition of Syawalan at Morodemak Village, District Bonang, Demak regency to reveal the meaning of the tradition for the community. Direct observations, interviews and examination of secondary data, explain that the tradition for the people of Morodemak, is a form of gratitude to the Almighty God for the gift of the abundance of seafood as well phrase prayer of salvation from all dangers that can arise from the sea. Tradition also has significance of Syawalan concern for nature, especially the sea as well as the meaning of cohesion and communality among fishing communities. In addition to these cultural meanings, tradition of Syawalan also has economic and socio-cultural significance for local government and communities.
\end{abstract}

Key words: Tradition, Syawalan, Java Coastal area, Demak, Sociocultural meaning.

\section{Pendahuluan}

Sejak dulu kala Indonesia dikenal sebagai bangsa yang memiliki kekayaan tradisi yang luar biasa banyak dan beragam. Keragaman tradisi tersebut didasarkan pada keragaman etnik dan budayanya yang tersebar di berbagai wilayah di Indonesia. Koentjaraningrat (2002) mengulas secara komprehensip tentang berbagai kebudayaan tersebut, seperti kebudayaan Batak, Ambon, Flores, Timor, Aceh, Minangkabau, BugisMakassar, Bali, Sunda, Jawa dan sebagainya. Salah satu kekayaan tersebut adalah tradisi Syawalan atau Sedekah Laut.

Syawalan atau sedekah laut merupakan salah satu tradisi yang populer bagi masyarakat pesisir atau nelayan di berbagai wilayah. Di Jawa Tengah tradisi Syawalan atau sejenisnya dilaksanakan oleh komunitas nelayan di wilayah-wilayah pantai di 
Cilacap, Tegal, Pekalongan, Batang, Weleri, Kendal, Kaliwungu, Demak, Jepara, Kudus, Juwana, Pati dan sebagainya. Syawalan atau sedekah laut serta tradisi-tradisi lainnya dalam pandangan Antropolog Ruth Benedict (1959) merupakan salah satu konstruk kebudayaan suatu masyarakat tertentu. Menurutnya, pada setiap kebudayaan terdapat nilai-nilai tertentu yang mendominasi ide yang berkembang. Dominasi ide tertentu dalam masyarakat akan membentuk dan mempengaruhi aturan-aturan bertindak masyarakatnya (rules of conduct) dan aturan-aturan bertingkah laku (rules of behavior) yang kemudian secara bersama-sama membentuk pola kultural masyarakat.

Semua adat kebiasaan atau tradisi-tradisi tersebut memiliki nalar kebudayaan yang melatarbelakanginya; selain ini juga memiliki makna luhur bagi orang-orang yang hidup di dalamnya. Berdasarkan hal tersebut dapat dipahami bahwa sebagai sebuah tradisi yang sangat populer, Syawalan memiliki latarbelakang nalar kebudayaan serta makna yang luhur tersebut. Tulisan ini mengungkapkan nalar kebudayaan pada tradisi Syawalan dan makna tradisi tersebut bagi masyarakat saat ini. Tulisan ini memfokuskan pada tradisi Syawalan yang dilakukan oleh komunitas pesisir di Morodemak, Bonang, Demak. Pengumpulan data dilakukan melalui pengamatan, wawancara dan studi dokumentasi.

\section{Tradisi Syawalan sebagai Konstruk Kebudayaan Jawa Pesisir}

Terdapat sejumlah konsep kunci untuk menganalisis lebih jauh tentang tradisi Syawalan yang banyak dilaksanakan oleh kalangan masyarakat pesisir Jawa ini. Masingmasing konsep kunci tersebut tidak berdiri sendiri, tetapi terkait satu dengan lainnya. Beberapa konsep kunci tersebut antara lain tradisi, kebudayaan, Jawa pesisiran. 
Kebudayaan adalah sesuatu yang tidak bisa dilepaskan dengan manusia. Antara manusia dan kebudayaan adalah sesuatu yang terkait erat. Secara bersama-sama, keduanya menyusun kehidupan (Kistanto, 2006: 2). Oleh karena itu dalam pandangan kalangan budayawan, manusia juga disebut sebagai makluk budaya. Pernyataan bahwa manusia sebagai makhluk budaya mengandung pengertian bahwa kebudayaan merupakan ukuran dalam hidup dan tingkah laku manusia (Herusatoto, 2008: 11).

Secara sempit kebudayaan sering diartikan sebagai kesenian. Pengertian ini dinilai mempersempit isi dan kandungan kebudayaan. Menurut Koentjaraningrat (1985: 19), kebudayaan adalah seluruh hal yang terkait dengan budi dan akal manusia. Oleh karena itu wujud kebudayaan bisa meliputi (1) sebagai suatu kompleks dan ide-ide, gagasangagasan, nilai-nilai, norma-norma, peraturan dan sebagainya, wujud ini bisa berada dalam alam pikiran warga masyarakat, berupa tulisan-tulisan serta karangan-karangan masyarakat tersebut; 2) sebagai kompleks aktivitas kelakuan berpola manusia dalam masyarakat, wujud ini berupa sistem hasil karya masyarakat yang bersangkutan; 3) wujud kebudayaan sebagai benda-benda hasil karya manusia, berupa bentuk nyata sebagai hasil karya masyarakat yang bersangkutan.

Lebih lanjut, menurut Koentjaraningrat $(1974,1985)$ kebudayaan berisikan tujuh unsur. Ketujuh unsur kebudayaan tersebut dipandang sebagai unsur-unsur universal kebudayaan. Oleh karena itu tujuh unsur tersebut merupakan isi dari semua kebudayaan di dunia, yang meliputi (1) sistem religi dan upacara keagamaan; 2) sistem dan organisasi kemasyarakatan; 3) sistem pengetahuan; 4) sistem bahasa; 5) sistem kesenian; 6) sistem mata pencaharian hidup; 7) sistem teknologi dan peralatan. Tradisi-tradisi yang berkembang pada masyarakat merupakan wujud dan bagian dari unsur kebudayaan, 
sebagaimana pandangan Benedict (1959), bahwa tradisi merupakan salah satu konstruk kebudayaan suatu masyarakat tertentu.

Berdasarkan konsep tentang tradisi dan kebudayaan tersebut, maka tradisi Syawalan sebagaimana yang dilakukan oleh masyarakat pesisir Jawa dapat dikatakan sebagai salah satu konstruk kebudayaan pada masyarakat Jawa pesisiran, yaitu sebuah kebudayaan spiritualitas. Oleh karena itu nilai-nilai yang mendominasi ide tradisi Syawalan tersebut adalah nilai-nilai yang diyakini pada umumnya masyarakat Jawa, khususnya Jawa Pesisiran.

Jawa merupakan salah entitas kebudayaan yang khas, terutama kebudayaan spiritualnya. Menurut Kodiran (Koentjaraningrat, 2002: 347) pada umumnya orang Jawa memiliki kepercayaan sebagai berikut. Pertama, bahwa hidup manusia di dunia sudah diatur alam semesta ini, sehingga pada umumnya orang Jawa memiliki sikap nerimo (menerima apa adanya) dan berserah diri kepada takdir. Manusia merupakan bagian totalitas alam semesta atau kosmos, manusia hidup tidak terlepas dengan lain-lainnya di alam jagad. Bila terdapat bagian yang mengalami kesukaran, maka manusia akan menderita juga. Kedua, bersama dengan pandangan alam partisipasi tersebut, orang Jawa juga percaya kepada kekuatan gaib atau kasekten pada benda-benda tertentu seperti tombak, keris, gamelan dan sebagainya. Oleh karena itu pada saat-saat tertentu orang Jawa melakukan ritual untuk penyucian benda-benda tersebut. Ketiga, orang Jawa juga percaya akan eksistensi arwah atau ruh para leluhur, makhluk halus seperti memedi, lelembut, tuyul, demit, jin dan lainnya. Makhluk-makhluk tersebut dipercayai menempati alam sekitar tempat tinggal mereka. Orang Jawa percaya bahwa ruh dan para makhluk halus tersebut dapat mendatangkan kesuksesan, kebahagiaan, ketenteraman ataupun 
keselamatan. Selain itu mereka juga dipercaya dapat menimbulkan gangguan pikiran, kesehatan bahkan kematian. Oleh karena itu orang Jawa memiliki pandangan bahwa kalau ingin hidup tanpa menderita gangguan seperti itu, orang harus berbuat sesuatu untuk mempengaruhi alam semesta dengan cara seperti laku prihatin (tirakat), berpuasa, berpantang melakukan perbuatan tertentu, serta melakukan selametan, memberikan sesaji dan sebagainya. Selametan dan sesaji adalah tradisi yang akrab dilakukan oleh masyarakat Jawa di berbagai pedesaan. Selametan dalam tradisi Jawa ini dilakukan sesuai dengan peristiwa dan kejadian dalam kehidupan manusia sehari-hari, seperti selametan dalam rangka peristiwa kelahiran dan kematian, bertalian dengan aktifitas bersih desa, berkaitan dengan kegiatan pertanian, berkaitan dengan hari-hari besar Islam, serta selametan yang berkaitan dengan peristiwa-persitiwa tertentu seperti menempati rumah baru, bepergian jauh dan sebagainya.

Sebagian antropolog membedakan entitas kebudayaan Jawa berdasarkan karakteristik geografisnya menjadi Jawa Pedalaman dan Jawa Pesisir. Seperti dijelaskan oleh Mujahirin Thohir (2006: 272), ciri orang-orang Jawa pesisir lebih egaliter, terbuka dan lugas; hal tersebut berbeda dengan karakteristik orang-orang Jawa Pedalaman yang pada umumnya menempatkan manusia secara berjenjang dan hierarkis. Model komunikasi orang Jawa Pedalaman juga tidak begitu terbuka sebagaimana orang Jawa pesisir.

Perbedaan kerakteristik Jawa Pedalaman dan Jawa Pesisir juga disebabkan persentuhannya dengan penyebaran Islam. Banyak teori yang mengukuhkan bahwa proses penyebaran Islam di Jawa berangkat dari wilayah pesisir. Proses penyebaran Islam di Jawa diperankan oleh para wali yang dikenal dengan sebutan Walisongo. Proses 
penyebaran Islam di Jawa oleh Walisongo menggunakan strategi dan metode akulturatif dengan kebiasaan atau tradisi setempat sehingga lebih mudah diterima. Menurut Nur Syam (2005: 69), melalui peran Walisongo inilah Islam berkembang dan melembaga di dalam kehidupan masyarakat, sehingga banyak tradisi yang dinisbahkan sebagai kreasi dan hasil cipta rasa Walisongo dan masih bertahan sampai sekarang.

\section{Morodemak, Profil Desa Pesisir}

Morodemak adalah desa pesisir laut dan berada di wilayah Kecamatan Bonang, Kabupaten Demak. Desa ini berhadapan langsung dengan Laut Jawa. Nama aslinya desa Morodemak, tetapi oleh orang-orang setempat dan sekitarnya lebih populer dengan sebutan Moro. Konon menurut cerita orang-orang daerah setempat, kata Morodemak berasal dari kata "Muara" dan "Demak". Muara artinya ujung dari aliran sungai yang mengantarkan sampai laut, sedangkan Demak menunjukkan tempat atau wilayah Kota Demak. Yang dimaksud adalah sungai Tuntang Lama, sebuah sungai yang bermuara langsung ke Laut Jawa. Sungai ini bila ditelusuri hulunya sampai di Kota Demak, melewati beberapa desa dan berakhir di Desa Morodemak. 


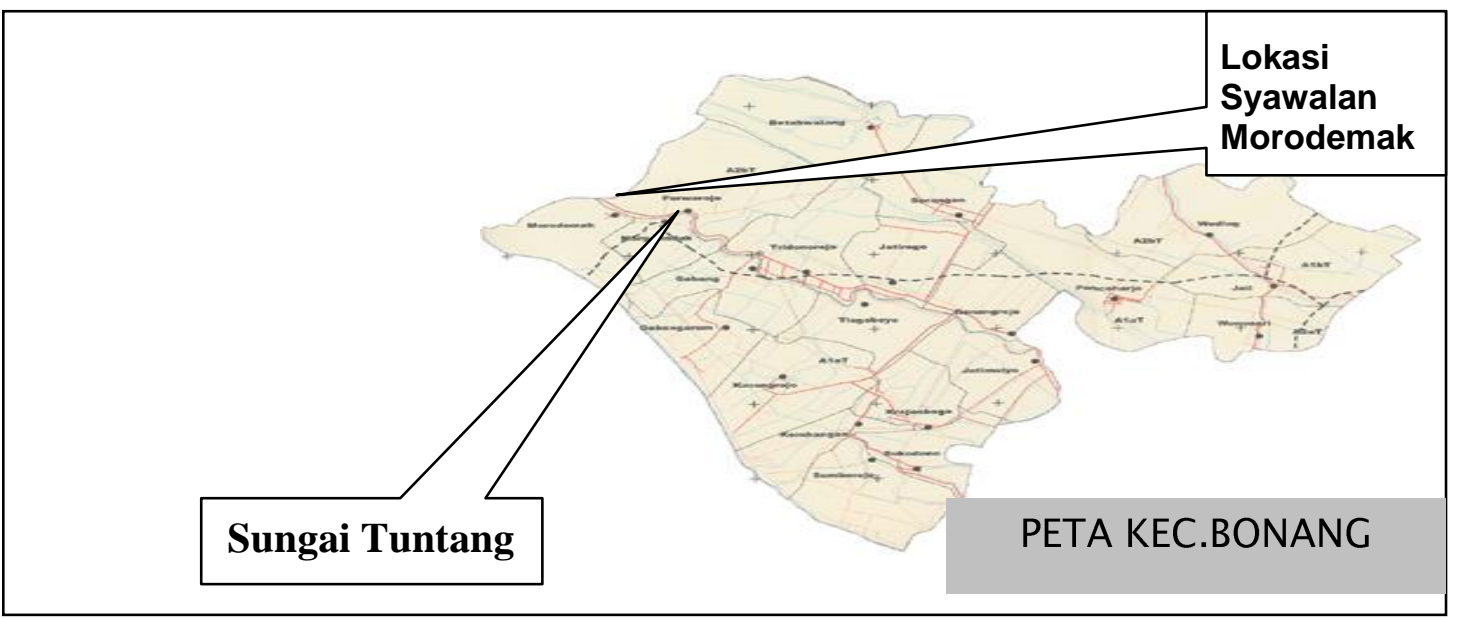

Desa Morodemak ini persis berada di tepi sungai Tuntang Lama itu. Bagian barat

desa adalah laut Jawa. Bagian selatan berbatasan dengan wilayah Kecamatan Karang Tengah. Bagian timurnya berbatasan dengan Desa Margolinduk, sedangkan bagian utaranya berbatasan dengan Desa Purworejo yang dipisahkan oleh sungai Tuntang Lama tersebut. Untuk sampai di desa ini pengunjung harus menyeberangi sungai yang lebarnya 25 meteran dengan jasa perahu tambangan.

Luas wilayah Desa Morodemak sekitar 4.262 Ha, sebagian besar merupakan hamparan rawa pesisir dan pertambakan. Selebihnya merupakan wilayah pemukiman. Tanahnya nampak sangat gersang, sejauh mata memandang tidak nampak sama sekali hijaunya dedaunan sebagaimana umumnya desa-desa lainnya. Jenis pepohonan yang ada hanya jenis tanaman bakau yang tumbuh di daerah pertambakan dan rawa-rawa pesisir. Tumbuhan bakau ini berfungsi untuk menjaga tanggul tambak dari gerusan air sungai atau laut.

Penduduk Desa Morodemak secara keseluruhan berjumlah 5036 jiwa yang terdiri 2135 orang laki-laki $(49,06 \%)$ dan 2901 orang perempuan $(50,94 \%)$. Seperti pada umumnya desa-desa nelayan pada umumnya, profesi kebanyakan penduduk adalah sebagai nelayan $(37,2 \%)$, petani tambak, baik sebagai penggarap (buruh) maupun sebagai 
pemilik $(9,24 \%)$, selebihnya sebagai pedagang, buruh bangunan, sebagiannya sebagai buruh industri di luar daerah. Dari segi pendidikan, bagian terbesar penduduk Morodemak hanya mengenyam pendidikan sampai SD (67,77\%), selebihnya lulus SLTP $(6,05 \%)$, SLTA $(3,40 \%)$ dan sampai perguruan tinggi $(1,30)$.

Tabel 1 menunjukkan jumlah penduduk Desa Morodemak menurut jenis pekerjaan pada tahun 2007; Tabel 2 menurut tingkat pendidikan (Morodemak, 2007), dan Tabel 3 tentang jenis-jenis kegiatan keagamaan.

Tabel 1: Jumlah Penduduk menurut Jenis Pekerjaan

\begin{tabular}{lll}
\hline \multicolumn{1}{c}{ Jenis Pekerjaan } & Jumlah & \% \\
\hline Petani (tambak) milik sendiri & 206 & 5,01 \\
Petani (tambak) buruh & 174 & 4,23 \\
Nelayan & 1876 & 37,2 \\
Wiraswasta Umum & 23 & 0,55 \\
Buruh industri & 28 & 0,68 \\
Buruh Bangunan & 116 & 2,83 \\
Pedagang & 64 & 1,55 \\
Angkutan & 48 & 1,16 \\
PNS/ABRI & 10 & 0,24 \\
Sopir & 17 & 0,41 \\
Pensiunan & 13 & 0,31 \\
Lainnya & 2468 & 46,20 \\
\hline Jumlah & $\mathbf{5 0 3 6}$ & $\mathbf{1 0 0 \%}$ \\
\hline
\end{tabular}

Sumber: Monografi Desa Morodemak, Tahun 2007.

Tabel 2: Jumlah Penduduk menurut Tingkat Pendidikan

\begin{tabular}{lll}
\hline \multicolumn{1}{c}{ Tingkat Pendidikan } & Jumlah & $\mathbf{\%}$ \\
\hline Tamat Perguruan Tinggi & 68 & 1,30 \\
Tamat SLTA & 172 & 3,40 \\
Tamat SLTP & 305 & 6,05 \\
Tamat SD & 3413 & 67,77 \\
Tidak Tamat SD & 118 & 2,34 \\
Belum Tamat SD & 918 & 18,22 \\
Tidak sekolah & 42 & 0,83
\end{tabular}




\section{Jumlah}

5036

$100 \%$

Sumber: Monografi Desa Morodemak, Tahun 2007.

Seperti pada umumnya daerah di Kabupaten Demak nuansa kehidupan keagamaan masyarakat Morodemak juga terasa sangat kental. Seratus persen penduduknya merupakan pemeluk Islam taat. Gambaran tentang suasana religius sangat nampak seperti setiap waktu sholat tiba, masjid-masjid dan langgar-langgar senantiasa ramai dengan jama'ah, baik laki-laki maupun perempuan, baik orang tua maupun kanak-kanak. Pada saat waktu sholat Mahrib, jama'ah hampir pasti penuh sesak memenuhi sudut-sudut masjid dan langgar. Pada saat itu biasanya para laki-laki yang bekerja sebagai nelayan telah kembali dari melaut.

Selain dalam masalah berjama'ah sholat, kegiatan-kegiatan keagamaan lain juga banyak diselenggarakan hampir setiap hari dari pagi sampai malam hari. Bentuk kegiatan keagamaan tersebut antara lain pengajian, manaqiban, yasinan, tahlil, barznjen, ziarah kubur, majlis dzikir dan sebagainya. Kegiatan-kegiatan tersebut ada yang diikuti oleh umum, baik laki-laki maupun perempuan, anak-anak maupun orang dewasa. Ada juga kegiatan yang khusus untuk anak-anak, khusus untuk perempuan, atau hanya kaum lakilaki dewasa saja dan sebagainya.

Tabel 3: Kegiatan-kegiatan Keagamaan

\begin{tabular}{llll}
\hline Bentuk Kegiatan & Peserta & Waktu & \multicolumn{1}{c}{ Tempat } \\
\hline Pengajian Harian & & & \\
Tertentu & Ibu-ibu & Pagi/Siang & Rumah Kyai/Masjid \\
Pengajian Tafsir Pagi & Umum & Pagi & Masjid \\
Pengajian Al-Qur'an & Anak-anak & Pagi/Malam & Rumah Kyai \\
Pengajian Kitab & Remaja & Malam/Pagi & Pesantren/Rumah kyai \\
Madrasah Sore/TPQ & Anak & Sore & Madrasah \\
Manaqiban & Umum & Temporal & Rumah tertentu \\
Yasinan & Umum & Temporal & Rumah tertentu \\
Berzanji & Umum & Temporal & Masjid/Langgar/Rumah
\end{tabular}




\begin{tabular}{llll} 
Ziarah Qubur & Laki-laki & Jum'at & Maqam (Pekuburan) \\
Sema'an Al-Qur'an & Umum & Temporal & Masjid/Langgar/Rumah \\
Pengajian Majlis Dzikir & Umum & Temporal & Masjid/Langgar/Rumah \\
\hline
\end{tabular}

Sumber: Data Lapangan

Tidak hanya dalam bentuk kegiatan, nuansa keagamaan juga terwujudkan dalam bentuk bangunan fisik masjid dan musholla yang rata-rata cukup megah dan artistik. Bangunan-bangunan tersebut merupakan hasil swadaya masyarakat setempat dengan cara sambatan (gotong royong).

\section{Syawalan: Pesta Sedekah Laut}

Banyak istilah yang digunakan untuk menyebut tradisi Syawalan yang diselenggarakan oleh komunitas warga Morodemak. Selain Syawalan, istilah-istilah tersebut seperti lomban, sedekah laut dan pesta laut. Istilah Syawalan berasal dari kata Syawal, nama salah satu bulan pada kalender Islam atau tahun Hijriyah. Disebut dengan istilah Syawalan karena tradisi tersebut dilaksanakan pada bulan Syawal, yaitu pada satu minggu setelah hari raya Idul Fitri. Perayaan Syawalan dijadikan momentum untuk menjalin silaturahmi dan kumpul dengan sanak keluarga yang tinggal di tempat jauh. Syawalan masih terkait dengan hari raya Idul Fitri yang biasanya disebut Bada Kupat atau Hari Raya Ketupat. Oleh karena itu biasanya pada saat prosesi Syawalan banyak warga yang merayakannya dengan membuat makanan ketupat dan opor ayam serta sambel goreng. Tradisi Syawalan juga sering disebut dengan istilah lomban, karena pada acara tersebut juga dilakukan berbagai lomba yang diikuti oleh komunitas nelayan setempat. Jenis cabang yang diperlombakan antara lain perahu atau kapal hias, adu cepat mendayung perahu, selam, renang, panjat pinang dan sebagainya. Sebagian lagi menyebut dengan istilah sedekah laut, karena inti dari kegiatan Syawalan adalah ritual 
melarung sesaji ke laut. Sebagian masyarakat juga menyebut dengan istilah pesta laut, karena merayakan kegiatan Syawalan dengan cara berpesta makanan bersama di laut atau di tepi laut.

Kapan sebenarnya tradisi Syawalan di Morodemak dimulai? Nampaknya tidak ditemukan data yang valid dan keterangan yang pasti. Kesulitan melacak awal tradisi ini karena pelaksanaan Syawalan di Morodemak tidak terikat peristiwa tertentu. Hal ini berbeda dengan tradisi Syawalan di beberapa daerah lainnya. Seperti tradisi Syawalan di Kaliwungu, Kendal yang dilakukan masyarakat setempat untuk memperingati wafatnya Kyai As'ari, seorang ulama' dan tokoh agama setempat yang sangat dihormati, pada setiap tanggal 8 Syawal. Tradisi Syawalan (lomban) di Jepara selain sebagai ungkapan syukur pada Tuhan, juga dimaksudkan sebagai peringatan terhadap kepahlawan Ratu Kalinyamat yang beberapa kali melakukan penyerangan terhadap Malaka yang dikuasai bangsa penjajah, Portugis. Di Cilacap dikenal dengan sebutan sedekah laut dan dilaksanakan pada bulan Syuro, pada hari Selasa atau Jum'at Kliwon, bukan pada bulan Syawal. Sedekah laut di Cilacap secara historis berkaitan dengan perintah Bupati Cilacap ke-3, Tumenggung Tjakrawerdaya III, kepada sesepuh nelayan Pandanarang, Ki Arsa Menawi untuk melarung sesajen di Laut Selatan pada hari Jum'at Kliwon bulan Syuro, tepatnya pada tahun 1875 . Pelarungan sesajen tersebut dimaksudkan untuk memberikan penghormatan dan persembahan kepada Ratu Laut Selatan atau Nyai Roro Kidul.

Tradisi Syawalan di Morodemak bermula dari kebiasaan masyarakat nelayan setempat pada puluhan tahun silam yang merayakan lebaran dengan menghias perahu mereka. Berbagai hiasan dibuat dari janur, kain sarung, jarit, bendera merah putih, botolbotol kosong dan aneka buah. Jumlah hiasan menunjukkan jumlah anak buah (jurag) 
perahu: jurag atau anak buah perahu pada umumnya masih tetangga atau famili dari pemilik perahu atau juragan. Juragan, jurag dan keluarganya turut serta dalam perayaan tersebut. Mereka berangkat dari rumah dengan membawa bekal makanan secukupnya, pada umumnya nasi atau ketupat opor ayam, sambel goreng udang dan sebagainya. Kemudian menuju tempat penjualan hasil laut atau kongsi, istilah masyarakar setempat. Sekarang tempat tersebut lebih dikenal sebagai Tempat Pelelangan Ikan (TPI), yang bagi para nelayan Morodemak dipandang sebagai sumber kehidupan mereka sebagai pencari ikan. Pelayaran dari rumah masing-masing menuju ke TPI tersebut dipandang sebagai wujud rasa syukur para nelayan yang menyandarkan hidupnya dari hasil laut. Di tempat inilah berkumpul beberapa kelompok nelayan dan keluarganya. Mereka merayakan lebaran dengan berpesta makanan bersama. Tidak ada perbedaan antara nelayan besar dan kecil, kaya dan miskin, mampu atau tidak. Semua berbaur dan menyatu menyantap makanan yang telah disiapkan dan dibawa dari rumah. Ritual makan bersama di atas perahu ini dimaksudkan sebagai selamatan. Nelayan yang tidak memiliki perahu mengadakan selamatan di rumah masing-masing. Dalam perjalanan waktu acara ini kemudian berkembang menjadi tradisi sedekah laut yang dilaksanakan dan menjadi agenda pariwisata pemerintah setempat.

Kegiatan Syawalan atau sedekah laut ini dilaksanakan secara rutin setiap tahun pada hari kedelapan bulan Syawal. Pelaksanaannya juga melibatkan pejabat Kabupaten (Bupati) yang secara simbolik turut serta dalam proses Selametan di laut. Meskipun Syawalan ini dikaitkan dengan nelayan Morodemak, sesungguhnya penyelenggaraan Syawalan ini melibatkan komunitas tiga desa yang pada umumnya bermatapencaharian sebagai nelayan. Ketiga desa tersebut adalah Morodemak, Purworejo dan Margolinduk. 
Identifikasi Syawalan dengan desa Morodemak atau Moro karena pada awalnya tempat pelelangan berada di Desa Morodemak sebelum dipindah di Desa Purworejo sekarang ini. Selain itu sebelum jumlah nelayan sebanyak sekarang, pada zaman dulu yang berprofesi sebagai nelayan kebanyakan adalah orang Morodemak.

Adapun acara ritual perayaan Syawalan di Morodemak ini meliputi rangkaian kegiatan sebagai berikut.

\section{(1) Ritual Selamatan}

Acara selamatan dilaksanakan dua kali, yaitu malam hari sebelum hari $\mathrm{H}$ dan pada pagi harinya. Selamatan pada malam hari sebelum hari H dilaksanakan di lokasi Kongsi atau Tempat Pelelangan Ikan (TPI) dengan tujuan agar acara Syawalan yang akan dilaksanakan pada pagi harinya berjalan lancar dan selamat. Acara selamatan diikuti oleh pengurus KUD, perwakilan tokoh ulama' dan tokoh masyarakat dari tiga desa, Morodemak, Margolinduk dan Purworejo. Acara selamatan diisi dengan kegiatan pembacaan tahlil dan do'a yang dipimpin oleh para ulama' untuk mendoakan kepada arwah leluhur.

Acara selamatan kedua merupakan ritual puncak yang dilaksanakan di tengah laut dengan menumpang perahu cothok dan kapal mini. Perahu dan kapal untuk acara selamatan dihiasi dengan hiasan khas, seperti janur, kain sarung, jarit, bendera merah putih, botol-botol minuman dan aneka buah. Ritual Selametan ini menggunakan sajian nasi tumpeng berbentuk gunungan yang berisi ingkung (masakan ayam utuh), sambal goreng, telur rebus, sayur, tomat dan sebagainya. Ritual ini diikuti oleh para pejabat pemerintah, tokoh masyarakat dan sejumlah ulama' dari tiga desa Morodemak, Purworejo dan Margolinduk serta para nelayan. 
Kegiatan selamatan puncak diawali dari TPI sebagai pusat kegiatan Syawalan, ditandai dengan penyerahan dua buah tumpeng oleh Bupati kepada panitia Syawalan. Selanjutnya nasi tumpeng dibawa ke tengah laut dengan kapal mini atau perahu yang telah dihias. Turut dalam kapal ini rombongan pejabat, tokoh masyarakat serta sejumlah ulama' dari tiga desa nelayan setempat. Sejumlah kapal nelayan mengikuti kapal pembawa rombongan prosesi selamatan. Sesampainya di tengah laut ritul dimulai dengan bacaan do'a-do'a secara bergiliran oleh tiga kyai dan ulama' perwakilan desa Morodemak, Purworejo dan Margolinduk. Selesai pembacaan do'a, nasi tumpeng dimakan bersama-sama dengan kalangan pejabat, tokoh masyarakat nelayan, pengurus KUD serta tokoh ulama. Satu tumpeng lainnya dilarung ke laut sebagai simbol kepedulian pada laut.

Ritual Syawalan di Morodemak ini berbeda dengan Syawalan di beberapa daerah lain. Tidak ada prosesi pelarungan kepala kerbau seperti yang dilakukan di beberapa daerah lain. Menurut seorang tokoh masyarakat setempat, H. Muhamad Salim, hal tersebut disebabkan praktek semacam itu bertentangan dengan ajaran Islam. Berikut petikan pendapatnya, "Tidak dibenarkan menurut ajaran Islam membuang sesuatu di laut. Apalagi sesuatu itu bisa dimanfaatkan manusia. Jika dilanggar sama dengan mubazir dan menjadi temannya syetan."

\section{(2) Perlombaan dan Hiburan Umum}

Setelah prosesi selamatan di tengah laut selesai, rombongan kembali lagi ke TPI dan menyaksikan berbagai hiburan dan perlombaan yang digelar oleh panitia untuk para nelayan. Jenis lomba yang diselenggarakan antara lain lomba menghias perahu atau kapal, panjat pinang, mendayung kapal, menangkap itik di sungai dan sebagainya, 
tergantung ketentuan panitia penyelenggara lomba. Lomba diikuti sejumlah nelayan dari tiga desa nelayan setempat. Semua perlombaan dilaksanakan di sungai depan TPI, jalur di mana kapal dan perahu nelayan hilir mudik setiap hari berangkat dan pulang melaut. Panjat pinang dilaksanakan di halaman Kantor TPI.

Panitia penyelenggara tidak hanya menampilkan hiburan perlombaan, tetapi juga menggelar berbagai hiburan, seperti jenis hiburan yang pasti ada adalah pementasan wayang kulit, pergelaran grup musik ndangdut, berbagai permainan anak-anak dan sebagainya. Acara hiburan ini berlangsung selama sepekan dan puncaknya pada hari ke delapan bulan Syawal.

Tradisi Syawalan ini merupakan pesta rakyat, karena dari inisiasi sampai pelaksanaan berasal dari komunitas nelayan tiga desa nelayan, Morodemak, Purworejo dan Margolinduk yang dikoordinasikan oleh pengurus KUD Mino Utomo selaku pengelola TPI setempat; pemerintah hanya memberikan dukungan yang bersifat membantu dan memfasilitasi. Tidak hanya diikuti oleh masyarakat setempat, tradisi Syawalan di Morodemak juga dikunjungi kurang lebih sepuluh ribu pengunjung dari berbagai daerah. Para pengunjung dari luar daerah ini pada umumnya memanfaatkan jasa angkutan perahu yang disediakan oleh nelayan-nelayan setempat ke tengah laut.

\section{Makna Tradisi Syawalan bagi Komunitas Nelayan Morodemak}

Sebagaimana dijelaskan sebelumnya bahwa banyak istilah yang digunakan untuk menyebut tradisi yang populer di kalangan komunitas pesisir seperti halnya komunitas nelayan Morodemak, antara lain istilah sedekah laut. Salah seorang tokoh masyarakat Purworejo, Haji Muhammad Salim menjelaskan sebagai berikut. 
"Kata sedekah berasal dari bahasa Arab shodaqoh yang berarti memberikan sesuatu kepada yang berhak menerima. Sesuatu itu bisa berupa uang, barang yang bermanfaat bagi manusia, atau bisa dimakan. Kata sedekah bisa mengandung daf'ul balak, menolak segala mara bahaya dan bencana seperti angin ribut, badai, ombak dan gelombang laut besar yang sewaktu-waktu bisa datang dan mengancam jiwa."

Konsep tentang sedekah laut yang dipahami oleh komunitas pesisir Morodemak sebagaimana diungkapkan Haji Muhammad Salim tersebut sama halnya dengan konsep tradisi-tradisi dalam masyarakat Jawa seperti sedekah bumi, selamatan, sesajen dan sebagainya. Berbagai upacara keselamatan tersebut terkait dengan ekspresi keyakinan orang Jawa yang percaya akan eksistensi arwah atau ruh para leluhur, makhluk halus seperti memedi, lelembut, tuyul, demit, jin dan lainnya. Makhluk-makhluk tersebut dipercayai menempati alam sekitar tempat tinggal mereka. Para makhluk halus tersebut dipandang bisa mendatangkan kesuksesan, kebahagiaan, ketenteraman ataupun keselamatan. Selain itu mereka juga dipercaya dapat menimbulkan gangguan pikiran, kesehatan bahkan kematian. Oleh karena itu bagi orang Jawa, kalau ingin hidup tanpa menderita gangguan seperti itu, orang harus berbuat sesuatu untuk memperngaruhi alam semesta dengan cara seperti laku prihatin (tirakat), berpuasa, berpantang melakukan perbuatan tertentu, serta melakukan Selametan, dengan memberikan sesaji dan sebagainya.

Begitu pula halnya penggunaan tumpengan sebagai piranti dalam selamatan pada sawalan di Morodemak juga tidak bisa dilepaskan dengan konsep keselarasan dengan alam dalam nalar kebudayaan Jawa. Tumpeng adalah makanan berupa nasi dan lauknya yang ditata mengerucut membentuk gunung. Dalam kosmologi Jawa, selain laut, pertanian atau persawahan, gunung juga memiliki nilai tinggi dan memegang peranan penting dalam tata kehidupan orang Jawa. Selamatan dengan menggunakan tumpeng juga 
mengingatkan adanya kekuasaan tertinggi yaitu Tuhan Yang Maha Kuasa yang wajib dimintai keselamatan dan pertolongan oleh manusia (Purwadi, 2007: 111).

Syawalan di Morodemak juga dimaksudkan sebagai ungkapan syukur komunitas nelayan Morodemak kepada Tuhan atas limpahan rizki dari laut yang selama ini dinikmati oleh para nelayan di tiga desa setempat. Wujud syukur tersebut selain diungkapkan dalam ritual-ritul do'a sebagaimana di atas, juga diungkapkan dengan wujud mengajak seluruh awak kapal dan keluarganya ikut merayakan Syawalan ke tengah laut. Tidak ada jarak antara juragan dan jurag. Mereka duduk dan larut dalam kebersamaan di atas kapal atau perahu menuju ke tengah laut. Sambil menikmati jamuan yang disediakan oleh pemilik kapal, mereka juga dapat menikmati sajian berbagai pertunjukan dan perlombaan yang sangat menghibur. Oleh karena itu, selain untuk kepentingan ritual dan spiritual, Syawalan bagi komunitas nelayan Morodemak juga merupakan momen untuk mencari hiburan. Hal ini sesuai dengan pandangan Abdul Ghoni, salah seorang tokoh masyarakat Morodemak yang juga menjabat sebagai wakil ketua KUD Mino Utomo, selain sebagai Modin desa setempat. Menurutnya tradisi Syawalan atau sedekah laut di Morodemak memiliki tujuan sebagai berikut.

"Pertama, tradisi Syawalan ini memiliki arti sebagai ungkapan syukur terhadap Tuhan atas segala riziki dari laut yang selama ini telah dinikmati oleh para nelayan. Kedua, sebagai hiburan masyarakat nelayan. Selama ini nelayan hanya melihat dan menikmati laut. Sangat sedikit kesempatan untuk menikmati hiburan-hiburan seperti menyaksikan musik dangdut, pementasan wayang kulit, hiburan anak dan sebagainya. Kesempatan itu tidak hanya menyangkut soal waktu tetapi juga ketersediaan uang. Oleh karena itu semua hiburan yang disediakan oleh panitia penyelenggara bersifat gratis, kecuali hiburan mainan anak-anak yang disediakan oleh penyelenggara jasa mainan anak."

\section{Simpulan}


Dari berbagai pandangan dan analisis dapat disimpulkan bahwa tradisi Syawalan di Morodemak merupakan tradisi yang mengekspresikan gagasan harmoni dari tiga dimensi kehidupan manusia, dimensi manusia dengan Tuhan, manusia dengan manusia dan manusia dengan alam. Syawalan pada dimensi hubungan manusia dengan Tuhan dimaksudkan sebagai ungkapan rasa syukur atas karunia Allah berupa limpahan rizki dari laut, dan sekaligus ungkapan permohonan perlindungan dari segala mara-bahaya yang muncul di laut. Pada dimensi hubungan manusia dengan sesamanya, Syawalan merupakan media harmoninasi di antara para nelayan beserta keluarganya, antara jurag dan juragan. Melalui tradisi Syawalan warga nelayan semakin rukun, guyub dan menguat rasa kebersamaan di antara mereka. Rukun, guyub dan kebersamaan manjadi kekuatan modal sosial masyarakat yang sangat penting bagi kehidupan masyarakat nelayan yang sering dihadapkan pada suasana sulit dan keras, khususnya kala di laut. Pada dimensi hubungan manusia dengan alam, Syawalan dimaksudkan memberikan kesadaran dan pembelajaran kepada masyarakat untuk memelihara alam, khususnya laut. Pelarungan sesaji yang digantikan dengan tumpeng ke laut sebagai penghormatan pada laut. Bagi nelayan laut adalah nadi kehidupan ekonomi mereka. Kelestarian laut sangat berkait dengan kelimpahan hasilnya. Dengan menjalin harmoni dengan lingkungan, khususnya laut, maka kehidupan ekonomi mereka akan terjamin di masa-masa mendatang. Inilah makna-makna di balik perayaan tradisi Syawalan di Morodemak.

Pada saat ini acara Syawalan di Morodemak yang dilaksanakan pada hari ke delapan bulan Syawal menjadi agenda pariwisata pemerintah setempat. Ribuan masyarakat daerah sekitar serta dari beberapa daerah lainnya datang ke Morodemak dan menyaksikan acara Syawalan tersebut. Sebagian dari mereka datang sekaligus untuk 
mengunjungi dan bersilataruhmi serta beridul fitri dengan kelurga, saudara dan teman di desa setempat. Untuk memasuki lokasi Syawalan, para pengunjung ditarik karcis masuk seharga seribu rupiah. Begitupun para pengendara motor dan mobil juga dikenakan biaya masuk, masing-masing dua ribu rupiah untuk sepeda motor dan lima ribu rupiah untuk mobil. Selain untuk menyaksikan berbagai pentas hiburan yang digelar, pada umumnya mereka memanfaatkan jasa perahu ke tengah laut, berenang dan bermain pasir di pesisir pantai Morodemak. Jasa untuk ke laut rata-rata tiga sampai lima ribu rupiah perorang untuk waktu sekitar 30 (tiga puluh) menit.

Banyaknya pengunjung yang datang ke lokasi Syawalan memunculkan peluang keuntungan ekonomi bagi masyarakat nelayan setempat dengan menyediakan jasa kapal dan perahu kepada para pengunjung yang ingin pesiar ke tengah laut. Mereka juga menyediakan lahan dan jasa parkir motor dan mobil. Bahkan tidak sedikit dari mereka menjadi pedagang dadakan yang menjajakan jajanan, minuman dan mainan hiburan.

Pada sisi lain tradisi Syawalan yang dilakukan komunitas nelayan dengan cara menghias perahu dengan berbagai hiasan khas, menyajikan dan berpesta makan bersama di antara keluarga jurag dan juragan semakin jarang nampak. Hanya perahu dan kapal yang ditumpangi pejabat dan mengikuti prosesi ritual selamatan saja yang dihias. Perahu dan kapal yang banyak hilir-mudik melalui sungai Tuntang Lama tampil biasa, berisi penuh para palancong luar yang ingin ke tengah laut, serta perahu dan kapal dengan sound-system yang distel sangat keras dan dipenuhi anak-anak muda setempat yang berjoget dan berjingkrak-jingkak mengikuti irama musik dangdut atau lainnya; bahkan tidak sedikit yang diselingi dengan minuman keras sampai mabuk. Dari kapal dan perahu yang ada di Morodemak, Purworejo dan Margolinduk justru lebih banyak yang bersandar 
berjajar di sepanjang tepai sungai Tuntang Lama tersebut dan tidak turut berpartisipasi dalam keseluruhan acara Syawalan.

Bila dilihat dari jumlah pengunjung, khususnya yang datang dari luar komunitas nelayan setempat, sesungguhnya pengunjung Syawalan saat ini lebih banyak dibanding dengan Syawalan-Syawalan di masa lalu. Namun seiring dengan peningkatan jumlah tersebut, dari serangkaian wawancara serta pengamatan nampak adanya dua kecenderungan yang menonjol terkait dengan tradisi Syawalan tersebut.

Pertama, kecenderungan perubahan orientasi Syawalan di kalangan komunitas nelayan Morodemak, dari kontestasi kebudayaan spiritual ke arah orientasi pragmatisekonomis. Kecenderungan tersebut diikuti dengan kecenderungan kedua, yaitu semakin menurunnya tingkat partisipasi warga komunitas dalam ritual dan perayaan Syawalan tersebut secara total sebagaimana pada masa lampau. Kesimpulan ini masih dini, oleh karena itu perlu dilakukan penelitian lebih mendalam dan pelaksanaan solusi lebih seksama.

\section{Daftar Pustaka}

Benedict, Ruth. 1959. Patterns of Culture. Boston: Houghton Mifflin Company.

Bohannan, Paul \& Glazer, Mark. 1998. High Point in Anthropology. New York: Alfred A. Knopf.

Geertz, Clifford. 1981. Abangan, Santri, Priyayi dalam Masyarakat Jawa. Terjemahan. Jakarta: Pustaka Jaya.

Herusatoto, Budiono. 2008. Simbolisme Jawa. Yogyakarta: Penertbit Ombak.

Kistanto, Nurdien H. 2006. "Wawasan Budaya dan Teori Kebudayaan." Bahan kuliah. Semarang: Universitas Diponegoro.

Koentjaraningrat. 2002. Manusia dan Kebudayaan di Indonesia. Jakarta: Penerbit Djambatan.

Gramedia.

- 1974, 1985. Kebudayaan, Mentaltas dan Pembangunan. Jakarta: 
Kusnadi. 2006. Konflik Sosial Nelayan, Kemiskinan dan Perebutan Sumber Daya Alam. Yogyakarta: LkiS.

Purwadi. 2007. Pranata Sosial Jawa. Yogyakarta: Cipta Pustaka.

Suwarno, Imam S. 2005. Konsep Tuhan, Manusia, Mistik dalam Berbagai Kebatinan Jawa. Jakarta: Radja Grafindo Persada.

Syam, Nur. 2005. Islam Pesisir. Yogyakarta: LKiS.

Thohir, Mudjahirin. 2006. Orang Islam Jawa Pesisiran. Semarang: Fasindo. 